\title{
Introduction: Interpreting British European Policy
}

\author{
Mark Bevir, Oliver Daddow and Pauline Schnapper \\ Corresponding author: Oliver Daddow
}

\begin{abstract}
Britain has had particular problems reconciling itself to the idea of being a 'European' actor and a wholehearted member of the EEC/EU since 1973. Now, potentially, the 'awkward partner', is edging towards the exit door of the EU because a membership referendum is an increasingly likely prospect in the coming years. The aim of this special issue is to consider how we can account for the present state of affairs by adopting an interpretivist perspective on British European policy over the past four decades. The article begins with a comprehensive review of the extant literature on Britain and Europe, and an elaboration of the 'traditions and dilemmas' framework within which the contributors have studied the empirical material in their articles. It then explains the major themes that connect the articles and suggests how future research might build on the agenda proposed in this special issue.
\end{abstract}

Keywords: Britain, European Union, interpretivism, Euroscepticism, referendum 


\section{Introduction: Interpreting British European Policy}

'If we leave the EU, we cannot of course leave Europe' (Cameron, 2013).

The UK formally acceded to the European Community (EC) when Prime Minister Edward Heath signed the Treaty of Rome on 1 January 1973, meaning that 1 January 2013 marked the fortieth anniversary of UK membership of what in 1993 became the European Union (EU). The question of whether or not Britain should 'join Europe' had been a growing source of consternation, contention and contestation within the Conservative and Labour parties throughout the period after the Second World War. It became most pronounced in the 1960s when the formal decision to apply was announced and 'Europe' was thrust to the centre stage of British politics. This was a decade of lofty rhetoric, false dawns and delicate diplomatic manoeuvring, as pro-European UK politicians struggled to persuade domestic and international audiences that the UK was ready to accept a European future. Two UK membership applications were vetoed by French President Charles de Gaulle, in 1963 and again in 1967. Throughout its period as applicant and member, UK politicians, diplomats and civil servants were involved in exhaustive negotiations aimed at fitting a large member state with global economic ties to the Commonwealth into institutional and economic arrangements carefully tailored to the necessities of creating a stable, long-term rapprochement between France and Germany (Wall, 2012). The sense that Britain 'missed the bus' and has forever been running to catch up has been pervasive (Young, 1998; the historiography surveyed in Daddow, 2004).

Clearly, it is not only the British who struggle to relate to the EU, not least because the organization is a perpetual 'moving target'. An experiment in regional governance 
(Verdun, 2012), the EU is a complex, 'inchoate' (Ruttley, 2002, p. 229), unwieldy institutional design which struggles to keep pace with an expanding membership (now 28; Croatia was the latest member to join on 1 July 2013). A stark growth in policy competences since the 1990s and the crisis in the Eurozone since 2008 have added further layers of complexity to the ways in which publics and governments relate to the EU economically, politically and strategically, as doubts about the union's future viability taint discussions about how to solve present problems (Taylor, 2008). Put simply, 'the European Union continues to baffle observers and participants alike' (Anderson, 2009, p. 79). That said, one of the themes of this special issue is that Britain has faced a peculiarly intractable set of problems when coming to terms with the idea of Europe and to the practices of the EU. It is not the fact of adapting to membership that has strained British credulity but the perceived magnitude of the adaptation that has been required for a former imperial power many of whose opinion formers have stubbornly 'clung to the notion that their country still had a special place and mission in the world and that Empire should continue' (Kennedy, 1985, p. 332). By attempting in June 2014, unsuccessfully, to prevent Jean-Claude Juncker from becoming EU Commission President, David Cameron was the latest UK Prime Minister to 'stand alone' in defence of an exceptionalist rendering of Britain's role in Europe. Mainstream media once again reported on Britain losing another battle in a continuing 'war' against the threat of 'federalism' from Brussels. Yet another 'behind closed doors' agreement, the Eurosceptics proclaimed, had kept the EU on the wrong track, 'not coming our way’ (Chapman 2014).

Forty years on from accession, it is arguable that two issues left unaddressed in 1973 have combined to give Britain a sense of semi-detachment from the EU during its years as an otherwise active member. First of all, it was far from clear how successfully the negotiated arrangements would work in practice, particularly on the economic side. Britain's role as a 
net contributor to the budget has been a persistent flashpoint in British-EU relations, particularly since the Margaret Thatcher-dominated feuds of the 1980s. Harold Wilson's Labour government had immediately renegotiated the terms of entry in 1974-5, but this provided only 'palliative measures which failed to correct the underlying problem' (Wallace, 2013, p. 541). EU budget disputes pitting 'us' against 'them' have become a regular fixture in the largely negative media coverage of the EU in Britain (for instance Barker, 2013). Secondly, at the level of national identity, no domestic consensus has formed around the idea of Britain being a truly engaged and leading player in the EU. The two-to-one vote by the UK public in favour of continued EC membership in the referendum of June 1975 has come under sustained assault as disputes over the current and future direction of the EU have permeated national political life in the UK. On top of inflammatory media stories (studied in de Vreese, 2007), weak leadership from Europhile politicians and an evident lack of public knowledge about (Usherwood, 2002, pp. 216-219), and empathy for, European governance structures across the Union (Daddow, 2011; Usherwood and Startin, 2013, p. 7) have combined to put Britain at the 'sceptical' end of public attitudes towards the organization when measured on a comparative basis. For example, an FT/Harris poll to mark the $50^{\text {th }}$ anniversary of the signing of the Treaty of Rome in 2007 found that $52 \%$ of Britons felt life had got worse since accession to the EC in 1973 (cited Vasilopoulou, 2013, p. 161). As with the Juncker debacle, David Cameron's pledge that a Conservative-led government will hold a referendum on Britain's membership of the EU in 2017 (Wintour et al, 2013) means that there has never been a more timely moment to analyze the material and ideational troubles Britain has encountered in 'Europe', because there is an increasing prospect that Britain may withdraw from the organization. It should also help draw out lessons for other member states seeking to confront a rising tide of Euroscepticism by plebiscitary vote. 
This special issue was put together critically to reflect on the UK's troubled encounter with 'Europe' at a momentous juncture in British-EU relations: the build-up to a possible 2017 referendum on UK membership. It seems far from certain that a vote, should it occur, will go in favour of continued membership (Clark, 2011). Even should a referendum not take place, there is a continued sense of crisis underpinning the conduct of British-EU relations and it is important to appreciate how this situation has arisen and to ask how best we understand and explain continuity and change in UK-EU relations from 1973-2013. Our approach has been to assess British-European relations using a framework which draws on and develops an emerging interpretivist approach within the human sciences more generally (Bevir, 2002; Bevir, 2005). Still rather diffuse (Schwartz-Shea and Yanow, 2012), and according to some critics philosophically and methodologically problematic (Dowding, 2004; Glynos and Howarth, 2008; Smith, 2008; Jackson, 2011, p. 204;), we believe that an agentcentred but not agent-only interpretivist perspective can offer something distinctive to the study of International Relations and national foreign policies (Bevir et al., 2014). To outline the nature of this contribution the goals of this introduction are threefold. First, we survey the existing literatures to which we speak and explain the framework the contributors worked to. Second, we give an overview of the arguments of each article and identify the most prominent narrative traditions which connect them. Finally, we sketch an empirical research agenda that will develop the insights garnered from the special issue.

\section{The European Issue in British Politics: An Interpretivist Perspective}

'Britain's relations with the movement towards creating a European Union or a United States of Europe provide examples both of genuine self-deception and of actual attempts to persuade the British people of things that the persuaders must have known were not true' (Beloff, 1996, pp. 2-3). 
This special issue investigates the complex webs of belief surrounding 'Europe' as a bone of contention in national political life in Britain by operating at the intersection of two complementary sets of literature. On the one hand, there is the work by political scientists on European integration and Euroscepticism treating Britain in comparative perspective. On the other, there is the detailed case study work from political history and IR on the evolution of British foreign policy, national identity and role in the world which takes 'Europe' as a prism through which to consider the contours of the debate between dominant and dissident visions of Britain's global role. Having surveyed the relevant literature, this section explains the rationale for the interpretivist approach and how it has been enacted by contributors in the special issue through an engagement with the concepts of situated agency, traditions and dilemmas.

\section{Literature Review}

The first set of literature with which our work intersects is the 'cottage industry' that has sprung up around the study of Euroscepticism among elites, publics and, latterly, at grass roots level. This research has emerged largely but not exclusively (see Flood, 2002) in the institutional settings of Sussex in the UK, and North Carolina in the US (Mudde, 2011, p. 4; Vasilopoulou, 2013, p. 156) and 'is now firmly established as a cross-disciplinary sub-field of European studies' (Flood, 2009, p. 912). As the appearance of a 2012 special issue of the Journal of Common Market Studies devoted to Euroscepticism shows, Euroscepticism can no longer be ignored by EU leaders, policy-makers or scholars, and the study of Euroscepticism has become an 'embedded and persistent phenomenon' in the practice as well as the study of contemporary European politics (Usherwood and Startin, 2013). These research communities have inspired a rich array of comparative qualitative work and large- $n$, longitudinal studies 
heavily steeped in the quantitative research tradition (landmark texts include Taggart, 1998; Ray, 1999). They generally seek to understand or map where Euroscepticism is and then to explain its emergence and appeal (Vasilopoulou, 2013), particularly but exclusively with reference to party systems and public opinion around the EU and candidate countries (Taggart and Szczerbiak, 2002; Guerra, 2013). The conceptual ground clearing and definitional work remain as significant to the enterprise today as at the beginning of the endeavour (Taggart and Szczerbiak, 2013, pp. 18-19), with healthy debates still occurring over how to categorize different 'strengths' of Euroscepticism ('hard' versus 'soft'), and about which typology best enables an accurate categorisation of party positions (see the critique of Taggart and Szczerbiak in Kopecký and Mudde, 2002).

A major player in the EU and a Eurosceptical state par excellence (Spiering, 2004), Britain remains a compelling case for scholarly attention within these communities - yet it is treated as one case amongst many and this limits the qualitative depth of information that single case approaches can generate. The focus remains largely on how the push and pull of the British party system produces governing 'preferences' on integration on particular issues such as treaty change (Aspinwall, 2004). Smaller- $n$ comparative work takes us some way to generating critical depth, particularly on the cultural context, national identity and discursive aspects of European integration dilemmas in domestic politics (for example Díez Medrano, 2003). Single case research has the benefit of generating genuine qualitative depth whilst not ruling out the possibility of contributing to cross-case comparisons (Gerring, 2001, p. 215). Moreover, as Ben Rosamond has observed, country-focused research brings the normative and analytical benefit of breaking down supposed barriers between the 'inside' of states and the 'outside' of European integration, and so is well placed to reflect the governing reality of a 'continuous and intimate interplay between the EU and national levels of authority' (Rosamond, 2007, p. 240). In this collection we have endeavoured to achieve a more nuanced 
understanding of the background beliefs that have informed what, historically speaking, the British have 'made' of 'Europe', and how these have fed through in European policy thinking in Downing Street and Whitehall (see also Gifford, 2008). Sensitivity to narrative traditions is important because we broadly agree with the now over a decade old finding of Marcussen et al. that 'identity constructions and myths' dating back centuries 'are so embedded in the national political culture [in Britain] than not even dramatic geo-strategic developments trigger discursive contestation' (Marcussen et al., 2001, p. 114). We seek to test the continuing applicability of this statement forty years after the supposedly momentous move of the British to secure a 'European' future.

This special issue therefore looks to develop the findings of the Euroscepticism research programmes in two regards. First, we situate party debates in the context of wider national narratives - particularly on the economy and national sovereignty - which cross-cut party political boundaries and infiltrate the national 'dialogue' surrounding British identity and the merits of a long-term role in European integration. We do not disagree that elites are significant sources and transmitters of Euroscepticism, but we try to go beyond seeing the Eurosceptical linguistic repertoire only or mainly in its rationalist guise, as a strategic tool of party competition (Baker et al, 2002; Hooghe, 2007). We are interested in ideas, beliefs and narrative traditions in their 'policy-shaping' guise (Cini, 2006, p. 40), an essential but not deterministic component of the decisions which have 'made' British European policy as it is, variously, understood today.

This focus cues our second motivation for the design of the special issue - it helps us rethink the problems surrounding the periodization of Euroscepticism (for instance Forster, 2002) and how this affects the kind of knowledge we can and have discovered about British attitudes to Europe more generally (on periodization issues see Vasilopoulou, 2013, pp. 158163). We suggest that 1945 has too often been depicted as a convenient 'origin' or starting 
point for investigating modern British attitudes to 'Europe' (good exceptions being Beloff, 1996; Young, 2000). Convenient, certainly, but not altogether convincing, downplaying as it does the residue in the post-Second World War era of pre-1945 internal Whitehall debates about the merits of engaging 'Europe' (see Daddow in this collection), and the accompanying angst about Britain's identity and role in the world that went with them (Schnapper, 2011; Crowson, 2011). With the 1993 Maastricht Treaty and the 2007 Lisbon Treaty regularly taken as vital turning points in the rise to popularity of Eurosceptical attitudes (Usherwood and Startin, 2013, pp. 3-4; Taggart and Szczerbiak, 2013, p. 17) across the EU and not just in Britain, it is important to reflect on how the potential importance of these critical junctures were perceived by the actors involved at the time, and how they made sense of them in the context of prior beliefs they had come to hold about Britain's place in the wider European grouping, hence our focus on historically informed narrative traditions as background influences on policy decision-making.

Through the interpretivist framework outlined below, the special issue speaks to a second category of literature on Britain and Europe. This interdisciplinary body of work European Studies in empirical and methodological orientation, as opposed to contemporary 'EU Studies' (McGowan 2008, p. 8; Warleigh-Lack, 2009) - looks to the historical, cultural and background ideas informing Britain's policy responses to European integration dilemmas. This work takes various guises: British politics and/or foreign policy that have an explicit (Baker and Seawright, 1998; Deighton, 2001; Williams, 2005; Holden, 2011; Oppermann, 2012) or composite European focus (Turner, 2010; Gaskarth, 2013); the history of British diplomacy toward the EC/EU (George, 1994; Ludlow, 1997; Wilkes, 1997; Parr, 2005; Gowland, Turner and Wright, 2010; Pine, 2012); political parties, civil society and other sectoral interests and European integration (Turner, 2000; Coupland, 2006; Crowson, 2007; Usherwood, 2007; Broad and Daddow, 2010; Lynch, 2011; Fitzgibbon, 2013); and 
accounts of the symbolism and cultural capital attached to Eurosceptical readings of the British (influentially Colley, 2005) - but most often English - national 'character' (Marcussen et al., pp. 111-114; Redwood, 2001, pp. 29-31; Paxman, 1999, pp. 24-42), particularly as expressed in media and other transmission devices (Anderson and Weymouth, 1999; Spiering, 2004; Leconte, 2010; Daddow, 2012). In taking this approach we have actively responded to calls by a series of writers in recent years to expand the empirical basis and theoretical framework for our studies of Euroscepticism. Suggestively for our special issue, we find much to recommend the view that interdisciplinarity, or perhaps more accurately multidisciplinarity (Warleigh-Lack, 2009; Usherwood and Startin, 2013; Vasilopoulou, 2013), and the exploration of 'resistances' to European integration offer fruitful ways forward, especially in so far as appreciating 'how the phenomenon is rooted and constructed within national political spaces', within and well beyond political parties (Crespy and Vershueren, 2009, p. 382). Party political discourses feature prominently within the contributions in this special issue, but they do so as part of a wider inquiry into the heritage of Britain's European travails over a much longer period than is acknowledged in the extant literature.

\section{Interpretivism as Social Ontology}

Interpretivists make a series of ontological and epistemological moves designed to cast fresh light on the ideational basis of political activity. Epistemologically, interpretivism shares affinities with, but is also distinctive from, constructivist and 'post-ist' approaches to the study of foreign policy and international relations (for instance Campbell, 1998; Epstein 2008). Interpretivists agree that the world does not come to us unvarnished (Bevir and Rhodes, 1999), revealed as if peeling back a curtain to look through a clear window on a series of 'given facts divorced from theoretical contexts' (Finlayson, 2005b, p. 132). 
Interpretivists do not deny either that there is a 'world' out there (they are epistemological sceptics not ontological nihilists), or that material power, institutions and discourses exist within that world (see for example the nuanced treatment of the dynamics of British foreign policy in Gaskarth 2013, especially pp.81-95). In the International Relations literature the latter are sometimes construed as 'myths' which shape foreign policy thinking (for instance Jones and Benvenuti, 2006, pp. 105-109). This anti- or postfoundational epistemology (Bevir, 2011) is suggestive because it compels attention to the linguistic as well as the material dimensions of political life: 'It understands politics itself as a kind of interpretive activity. Political movements develop a particular interpretation of the world and attempt to secure the victory of that interpretation over others so that it ceases to appear as an interpretation and looks to be the truth' (Finlayson, 2005a, p. 154). In this special issue the contributors have tried to interpret the 'sense' individual British decision-makers and sometimes whole parties or factions thereof have come to hold about who the British are in identity terms, how these individuals and groups have 'read' British foreign policy interests, and how they have represented the EC/EU as object and outlet for the expression of these interests. Throughout, we have tried to recognize that both 'Britain' and 'Europe' are contested and evolving terms, sometimes maddeningly imprecise and always open to contestation - not least by today's Eurosceptics (Pagden, 2002). Examining the dynamic interaction between these interconnected 'layers' of interpretation represents both methodological challenge and epistemological opportunity, so it is now necessary to unpack the precise nature of our intervention, centring on the notion of situated agency, traditions and dilemmas.

The easiest way to distinguish interpretivism from constructivism and post-ist renderings of political action is to understand why and how interpretivists work the concept of situated agency, which in this special issue takes the form of an engagement with the notion of traditions and dilemmas. The key here is the recognition that: "Agency always 
occurs against a particular historical background that influences it' (Bevir et al., 2013, p. 167). Interpretivists also appreciate that patterns of behaviour and language can be repeated into sometimes startlingly prominent patterns over time. Indeed, British European policy discourses have been found to exhibit just this tendency (Daddow, 2011). However, interpretivists differ from 'thin' constructivists who 'add ideas and stir' into an essentially materialist and/or institutionalist account of foreign policy activity. They also distinguish themselves from post-structuralists who treat the language or 'discourses' of foreign policy and national identity as structural constraints on political decision-making (Bevir et al., 2013, pp. 166-167), and from postmodernists who go to the other extreme by positing 'a near infinite number of mutually exclusive subject positions or vantage points from which the world can be viewed differently' (a useful distinction within the post-ist movement drawn by Hay, 2011, pp. 170-171; see also the critique in Glynos and Howarth, 2007).

Situated agency is therefore used by intereptivists to engage the agency-structure problem in the analyzis of political action (Carlsnaes, 1992) by working the interplay between 'context and conduct' (Hay, 2011, p. 176). The interpretivist focus is mainly on agents, but they are treated empathetically and as far as possible on their own terms, as individuals or collections of humans who have the capacity to affect their environment, whilst recognizing that they are also products of the various contexts within which they act: socially, politically and ideationally. As B.A.S. Koene describes it (2006, p. 366): 'institutional entrepreneurs have to operate from within an institutional context that already defines meaning and individual action and which, by definition, also affects the understanding and behaviour of the individual entrepreneur'. Ideational structures are no less real for being in the mind, yet as situated agents individuals or like-minded groups of individuals have the capacity to bring about change if they have the sufficient will, capacity and, importantly, if they can acquire constitutionally (for examples at elections) the formal or informal means to 
build support for a particular position (Kabele, 2010). The way we approach British European policy in this special issue is to see it as the outcome of ideational and in some cases ideological contestation about British identity and the meaning those prior traditions give to policies that have been pursued toward the EC/EU.

A tradition is 'a set of understandings someone receives during socialization', and comprises a dynamic relationship between beliefs and practices (Rhodes, 2007, p. 1250). A dilemma 'arises for an individual or group when a new idea stands in opposition to existing beliefs or practices and so forces a reconsideration of the existing beliefs and associated tradition' (Rhodes, 2007, p. 1253). Dilemmas bear the weight of causality in the interpretivist account of political change (Glynos and Howarth, 2008, pp. 158-159) because: 'Traditions change as individuals make a series of variations to them in response to any number of specific dilemmas' (Rhodes, 2007, p. 1253). Change for interpretivists occurs contingently (but not randomly - see Rosamond, 2007) 'as people reinterpret, modify, or transform an inherited tradition in response to novel circumstances or other dilemmas' (Bevir, 2010, p. 427). Summing it up, Birgitte Poulsen explains that 'it is through the occurrence of dilemmas that agency constantly transforms and reinvents existing traditions' (Poulsen, 2008, p. 121; see also Hay, 2011, pp. 178-179; Wilkinson, 2011). All contributors to this special issue explored the usefulness of traditions to the study of British identities, British attitudes and policies towards the EC/EU. They investigated how past British thinkers and policy actors conceived of, extended, modified, and dismissed traditions of thought and/or how these traditions have influenced Britain's policy and practice towards 'Europe'. Key questions asked by the contributors are: What are the leading traditions of British national identity? How do they relate to other traditions of knowledge about British society, the state, and Britain's place in the world? How did particular thinkers or groups (for example political parties) modify and renegotiate these traditions in response to novel circumstances and 
dilemmas? How have these traditions evolved over time? How did these traditions influence policy actors? What has been the relationship between thinking about British identity and Britain's changing role in Europe? Having explained the literatures we intersect with and the interpretivist intervention we seek to make, this article now delineates the main themes running through the articles in the special issue.

\section{The Articles in this Special Issue}

The articles in this special issue are loosely grouped around two sets of issues. The first explores the background beliefs held by British elites and the public on the question of national identity, which together inform the particular brand of Euroscepticism found today in Britain. Piers Ludlow provides much needed historical background to contemporary debates by looking at the crucial six-day House of Commons debates on membership of the EEC in October 1971. He finds that Conservative and Labour politicians opposed to membership referred to a number of 'British' traditions such as free trade, the Commonwealth/internationalist tradition - which we will come back to below - and parliamentary democracy, which in their view clashed with the principles underlying European integration and therefore made it threatening to British identity and interests. These techniques for framing the Europe question in British political discussions are important in helping us understand how the debate about 'Europe' has unfolded during the membership years since 1973.

Michael Kenny and Helen Brockelhurst both provide more contemporary general backgrounds to the Eurosceptic imaginary in Britain by focussing on attempts to redefine Britishness and Englishness in public debates and in the history curriculum for schools. Both articles show the extent to which this has tended to exclude European integration or at least make it problematic to identify positively with it. For Kenny, Euroscepticism has flowed 
from an increasingly 'Anglo-centric' conception of English identity, which rejects both Britishness at home and supranationalism abroad. In this perspective the recent success of UKIP, an insular and populist party with no roots outside England, is testimony to an entrenched unease with the European project among large sections of the English population. Kenny identifies several competing narratives of Englishness - a conservative romantic one trying to restore a unique England that pre-existed Britain and popularised by authors such as Roger Scruton, for whom national identity was threatened by participation in the European project; a radical-democratic one, represented by Tom Nairn, which identifies a void at the heart of English identity and a lack of a democratic English tradition, with 'Europe' presented as a possible remedy to the identity vacuum felt in England; finally a liberal 'Anglo-Britain' tradition following Michael Oakeshott, which continues to argue, unlike the previous two, that Britain as a democratic parliamentary system is a satisfactory entity with which the English can identify and that Europe is a successful opening to globalisation. Kenny's own conclusion is that these different views possibly fail to take account of the fluid and contingent realities of Englishness. By investigating the construction of national history as reflected in school curricula, Helen Brocklehurst reaches similar conclusions in her article on the connections between history curricula and national state-building projects. Focussing on the 'great debate' about the teaching of British history in the 1980s Brocklehurst sees British state school history curricula being imbued with Conservative ideology during the Margaret Thatcher years. She tracks how the essence of this curriculum survived the shift from Conservative to New Labour government in the 1990s and 2000s, and finally reflects on Michael Gove's push for more national history to be taught in schools under the Coalition government since 2010 .

Oliver Daddow's article goes further in this direction by examining the evolution of the 'outsider' tradition in the articulation of British foreign policy after the Second World 
War. By drawing on its historical lineage as an outside balancer in Europe, elites represented Britain as 'exceptional', linked to the continent but not 'of it', as Winston Churchill put it. British power in this widespread view came from it being a global actor, materially and ideationally. Its engagement in Europe was part of a 'limited liability' strategy, a necessary evil which could never prove as fulfilling as its 'special relationship' with the US and its continued leadership of the Commonwealth. This tradition remains the starting point of many contemporary narratives about British European policy. It has taken several forms since the $19^{\text {th }}$ century, with Britain playing different roles in time in Europe - first a balancer but with clear tendencies towards keeping out of continental European affairs unless pushed after the 1860s (1815-1939), then a supporter (1939-55), a saboteur (1955-56), a rival (1956-60), a supplicant (1960-73) and finally an insider (since 1973). Continuing debates and divisions about membership of the EC/EU as well as the return of a debate on withdrawal are evidence that the last phase marked an inflection rather than a disavowal of the ousider tradition indeed Daddow finds numerous references to previous outsider periods in Prime Ministers' rhetoric since the later Margaret Thatcher years, especially through their continued stress on the need for Europe to 'reform'.

This first set of articles alights on two main narrative traditions framing many political actors' negative perceptions of Europe, which the second set of articles develops - a technocratic/modernist one and a Commonwealth/empire tradition. The technocratic/modernist tradition focuses on the economic consequences of EU membership. It does not necessarily lead to Eurosceptic views, as the example of New Labour showed. While globalisation was at the core of its analyzis of Britain's place in the world, key New Labour people concluded, in what David Baker et al. called an 'open regionalist' view, that engagement with Europe could be an important step to making the most of life in a globalized world (2002a). Similarly, as noted by Craig Parsons and Cary Fontana, some pro-European 
figures in the Conservative party in the 1980s and 1990s connected neoliberalism and technocratic cosmopolitanism, fitting them with the European project. Reference to the technocratic/modernist tradition is now to be found mostly within the Conservative party and in the rhetoric of UKIP. Drawing on the classical economic tradition as well as a more recent Thatcherite neo-liberal thought, it portrays Britain's economic prosperity as based on its openness to free trade and liberalism and sees the EU as an obstacle to Britain's fully enjoying the fruits of globalisation by restricting access to global markets and imposing regulations which limit the competitiveness of European companies. This view, described by Baker et al. as 'hyperglobalist', now informs the attitudes of many Conservatives, justifying the demands of some for withdrawal from the EU (2002a). It was not always the case, as Parsons and Fontana remind us, because in the early 1960s the benefits of trading with its neighbours justified, in the view of many Conservatives, joining the EC, not leaving it.

In their article, Parsons and Fontana advance the interpretivist agenda by reflecting on the diverse ways in which elite actors remain 'situated agents'. In their analyzis of Conservative Euroscepticism they point to the key role played by Margaret Thatcher, both as Prime Minister and after her downfall, as a catalyzt for the radicalisation of party positions towards Europe. She combined a strong belief in neoliberalism with equally strong nationalist instincts and attachment to sovereignty, a seeming contradiction which Euroscepticism solved. They argue that with EEC/EU enlargement and a liberal European Commission in Brussels, the Conservative Party could have become more comfortable with the EU after she left power. It took Thatcher's influence and a number of contingent events, including the Danish 'no' vote on the Maastricht treaty in 1992, for a Eurosceptic discourse to take intellectual hold of a group of MPs and then spread throughout the party as a whole.

In his article on the dilemmas of contemporary British conservatism, Mark Vail points to the paradox that the neoliberal populist euroscepticism embodied by David Cameron was 
pursued in parallel with the monetarist and austerity-led policies of the German government and the European Central Bank. In other words, technocratic neoliberalism à la Cameron has converged with German policy at the same time as he has been distancing Britain from Europe. To him this is the result of unresolved tensions between two Conservative traditions, neoliberalism and One-nation Toryism. The Prime Minister's popular and populist Euroscepticism, in this vision, concealed the extent of the divisive spending cuts programme at home, a result of neoliberal ideology which clearly broke with the One-nation tradition.

The second tradition on which contemporary British Euroscepticism draws is a sentimental vision of the Commonwealth. It is grounded not only in the history of the close links between the UK and its former colonies but also in the idea that they still share a number of institutions, common law and values which set their relation apart from, and above, those enjoyed with other countries, especially in Europe. It was mostly used in the political debate in the 1960s and 1970s but has made a surprising comeback, under different guises, since the early 2000s. One aspect has been the reference among Conservative eurosceptics to an "Anglosphere" with former dominions and the US, which is seen as offering a possible alternative to European integration. Ben Wellings and Helen Baxendale show in their article that the Anglosphere model appeals to a British national narrative of the 'open sea' tradition, while providing the possibility of a future for Britain outside the EU. Suddenly the past is no longer only the past but offers hope for a better future. Conservative MP John Redwood, MEP Daniel Hannan, Boris Johnson, the Mayor of London and Conservative MP Bill Cash, who chairs the European Scrutiny Committee in the House of Commons, are among the most articulate proponents of such a calling, but echoes of it can be found in the rhetoric of David Cameron and William Hague, who have been keen to promote links with Commonwealth countries since 2010. The open sea tradition is related to the neoliberal tradition via a focus on free trade and globalisation. However, it adds a resonant 
historical, institutional and emotional dimension to it through evocation of imperial grandeur and global familial connections.

The case of UKIP is interesting in that it draws from both of the technocratic and Commonwealth traditions. Karine Tournier-Sol shows the extent to which UKIP identifies the EU as undemocratic and argues that Britain has a different history, which echoes the Commonwealth tradition. Nigel Farage indeed defines his party as 'the Party of the Commonwealth'. At the same time he articulates a Conservative and populist view of Britain as a global, not a regional power which can prosper outside the EU by ridding itself of costly regulations and promoting free trade with third countries, especially in the Commonwealth.

Finally, Pauline Schnapper examines the dilemmas faced by the Labour party under Gordon Brown and Ed Miliband. She argues that, unlike Tony Blair, they have resorted to a cautious pro-Europeanism, qualified by many criticisms of the way the EU works, which is reminiscent of Hugh Gaitskell and Harold Wilson in the 1960s. Like them, Brown and Miliband insisted on the shortcomings of the EU with reference less, as with their Conservative counterparts, to the Commonwealth tradition, but instead to the broader notion of British exceptionalism. In this rendering, Britain's destiny is to be multilateralist, a bridge between Europe and America and an open free trading nation. This suggests a strong continuity with Gaitskell and Wilson's internationalism and attachment to the Commonwealth. As a result, membership of the EU is of benefit to the UK, provided it remains mostly intergovernmentalist and 'reforms' itself - an ubiquitous term in contemporary Labour discourse, meant to apply to the euro crisis, unemployment in Europe, the budget and many other sectors - resulting in a return to a Labour soft Euroscepticism redolent of the 1960s.

\section{Future research}


The interpretivist framework set out in this special issue offers possible channels for future research: more on the British case study itself, and the broader comparative perspective, which would compare and contrast British narrative traditions about Europe with those of other countries in and outside the EU. First, the contributions in the special issue have generally sought to outline what has broadly been construed as a 'Eurosceptical' tradition of thought about Britain's relations with Europe. The authors have agreed that this tradition draws on an historically constituted 'outsider' tradition which has popularised among the British public and elites the idea that a whole-hearted continental commitment is something to embraced at best cautiously or at worst shunned altogether. The post-1980s 'Eurosceptical' adaptation of this tradition saw situated agents across the main political parties gain traction from this narrative by adding to it a series of concerns about the direction of European integration on economic, strategic, sovereignty and identity grounds.

What the special issue was less able to cast light upon was the power dynamics between the Eurosceptical tradition and rival, pro-European narratives, which have been the preserve of the liberal broadsheet press, in the Liberal Democrat Party itself, and among a dwindling band of openly Europhile politicians in the Labour and Conservative parties. The undoubted popularity of the liberal-minded 'missed opportunity' interpretation of British European policy often belied its impact on Britain's European policy thinking, even under notionally Europhile UK governments (Liddle, 2014). Its fate under the Coalition government since 2010 seems to have been all but sealed by two developments. One has been the crisis in the Eurozone which has undermined the strength of an economic case for a proactive European policy. The other has been the continued resonance of popular and political Euroscepticism within the Conservative Party, UKIP and large sections of the media, and a lack of confidence among Liberal Democrat members of the government of parliamentary party to speak up on an issue that has the potential to prove extremely divisive 
within the coalition as a whole. It seems probable therefore, that Britain's national debate about Europe will continue to draw on the Commonwealth/open seas or the technocratic/liberal narrative traditions identified in this special issue. Should Britain eventually hold a referendum on EU membership, this would obviously be a good place to begin the search for rival narratives, and to study their lineage back through the historical debates about Britain's role in Europe and the wider world.

Another fruitful line for future research would be to study the diverse ways in which nations in and outside the EU have related to the organisation on the back of the collective beliefs about the meaning of 'Europe' in domestic political and cultural life, national identity questions, and their preferred role in the world. This comparative work could certainly be effected using the traditions and dilemmas framework in this special issue. Excellent work in this area has previously been carried out to by Vivien Schmidt who follows an discursive institutionalist approach (Schmidt, 2001 and 2008) and by Marcussen et al in a constructivist vein (1999). However, the tradition and dilemmas approach provides other opportunities for future comparative analyzis, looking not just at national narratives but also how agents have adjusted them to new dilemmas. Debates about the future of the EU, the Eurozone and the socalled 'democratic deficit' across the EU would provide interesting case-studies in that respect. What a study of other countries would help us cast much needed light on is the nature of the narratives that sustain the exceptionalist rendering all national identity constructions, even as they come together to pool sovereignty in a collective integrative endeavour aimed at solving shared problems that are no longer felt adequately to be addressed by states acting independently. The British have had particular problems adapting to the challenges that engaging in a collective European endeavour have posed to much cherished historical sense of 'Britain' as international actor. An interesting task is now to discover how far the British 
have been alone in this, or what it has been about the European project itself that has come to prove so divisive to so many in such a relatively short space of time.

\section{References}

Anderson, P. (2009) The New Old World (London: Verso).

Anderson, P.J. and Weymouth, A. (1999) Insulting the Public? The British Press and the European Union (London: Longman).

Aspinwall, M. (2004) Rethinking Britain and Europe: Plurality Elections, Party Management and British Policy on European Integration (Manchester: Manchester University Press).

Baker, D. and Seawright, D. (eds) (1998) Britain For and Against Europe: British Politics and the Question of European Integration (Oxford: Clarendon Press).

Baker, D. Gamble, A., Randall, N. and Seawright, D. (2002) 'Euroscepticism in the British Party System: "A Source of Fascination, Perplexity, and Sometimes Frustration".' In Szczerbiak, A. and Paul Taggart, P. (eds) Opposing Europe? The Comparative Party Politics of Euroscepticism, Volume One: Case Studies and Country Surveys (Oxford: Oxford University Press), pp.93-116.

Baker, D., Gamble, A. and Seawright, D. (2002a), 'Sovereign Nations and Global Markets: Modern British Conservatism and Hyperglobalism', British Journal of Politics and International Relations, Vol. 4, No. 3, pp. 399-428.

Barker, A. (2013) 'David Cameron decries EU budget "ambushes" at summits', Financial Times, 28 June. Available at: <<http://www.ft.com/cms/s/0/33bf2738-e002-11e2-9de600144feab7de.html\#axzz2kifzFuI0>>. 
Beloff, Lord (1996) Britain and European Union: Dialogue of the Deaf (Basingstoke: Macmillan).

Bevir, M. (2005) New Labour: A Critique (Abingdon: Routledge).

Bevir, M. (2002) The Logic of the History of Ideas (Canbridge: Cambridge University Press).

Bevir, M. (2011) 'Political Science After Foucault', History of the Human Sciences, Vol. 24, No. 4, pp. 81-96.

Bevir, M. and Rhodes, R. (1999) 'Studying British Government: Reconstructing the Research Agenda', British Journal of Politics and International Relations, Vol. 1, No. 2, pp. 215-239.

Bevir, M. and Rhodes, R. (2007) Governance Stories (London: Routledge).

Bevir, M., Daddow, O. and Hall, I. (2013) 'Introduction: Interpreting British Foreign Policy', British Journal of Politics and International Relations, Vol. 15, No. 3, pp. 163-174.

Bevir, M., Daddow, O. and Hall, I. (2014) Interpreting Global Security (Abingdon: Routledge).

Broad, M. and Daddow, O. (2010) 'Half Remembered Quotations from Mostly Forgotten Speeches: The Limits of Labour's European Policy Discourse', British Journal of Politics and International Relations, Vol. 12, No. 2, pp.205-222.

Campbell, D. (1998) Writing Security: United States Foreign Policy and the Politics of Identity (revised edition) (Minneapolis, MN.: University of Minnesota Press).

Carlsnaes, W. (1992) 'The Agency-Structure Problem in Foreign Policy Analyzis', International Studies Quarterly, Vol. 36, No. 3, pp. 245-70. 
Chapman, J. (2014) 'Loser Cameron branded the "Rooney of Europe": PM warns Britain is in a "war" with EU after leaders railroad through appointment of arch-federalist Juncker', Daily Mail, 27 June. Available at: $<$ http://www.dailymail.co.uk/news/article2671985/Angry-Cameron-warns-European-leaders-consequences-Cognac-breakfastBrussels-fixer-Jean-Claude-Juncker-given-EUs-job.html>> .

Cini, M. (2006) 'The "State of the Art" in EU Studies: From Politics to Interdisciplinarity (and Back Again?)', Journal of Common Market Studies, Vol. 26, No. 1, pp. 38-46.

Clark, T. (2011) 'EU referendum: poll shows 49\% would vote for withdrawal', Guardian, 24 October. Available at: $<$ http://www.theguardian.com/world/2011/oct/24/eu-referendumpoll-uk-withdrawal?guni=Article:in\%20body\%20link $>>$.

Colley, L. (2005) Britons: Forging the Nation 1707-1837 (Yale: Yale University Press).

Coupland, P.M. (2006) Britannia, Europa and Christendom: British Christians and European Integration (Basingstoke: Palgrave Macmillan).

Crespy, A. and Vershueren, N. (2009) 'From Euroscepticism to Resistance to European Integration: An Interdisciplinary Perspective', Perspectives on European Politics and Society, Vol. 10, No. 3, pp. 377-393.

Crowson, N.J. (2007) The Conservative Party and European Integration since 1945: At the Heart of Europe? (London: Routledge).

Crowson, N.J. (2011) Britain and Europe: A Political History since 1918 (Abingdon: Routledge).

Daddow, O.J. (2004) Britain and Europe since 1945: Historiographical Perspectives on Integration (Manchester: Manchester University Press). 
Daddow, O. (2011) New Labour and the European Union: Blair and Brown's Logic of History (Manchester: Manchester University Press).

Daddow, O. (2012) 'The UK Media and "Europe": From Permissive Consensus to Destructive Dissent', International Affairs, 88, 6, pp.1219-1236.

De Vreese, C. (2007) 'A Spiral of Euroscepticism: The Media’s Fault?’, Acta Politica, Vol. 42, No. 2/3, pp. 271-286.

Deighton, A. (2001) 'European Union Policy.' In Seldon, A. (ed.) The Blair Effect: The Blair Government 1997-2001 (London: Little, Brown and Company), pp. 307-328.

Díez Medrano, J. (2003) Framing Europe: Attitudes to European Integration in Germany, Spain, and the United Kingdom (Oxford: Princeton University Press).

Dowding, K. (2004) 'Interpretation, Truth and Investigation: Comments on Bevir and Rhodes', British Journal of Politics and International Relations, Vol. 6, No. 2, pp. 136-142.

Epstein, C. (2008) The Power of Words in International Relations: Birth of an Anti-Whaling Discourse (London: MIT Press).

Finlayson, A. (2005a) 'Meaning and Politics: Assessing Bevir and Rhodes', British Journal of Politics and International Relations, Vol. 6, No. 2, pp. 149-156.

Finlayson, A. (2005b) 'The Interpretive Approach in Political Science: A Symposium Introduction', British Journal of Politics and International Relations, Vol. 6, No. 2, pp. 129136.

Fitzgibbon, J. (2013) 'Citizens Against Europe? Civil Society and Eurosceptic Protest in Ireland, the United Kingdom and Denmark', Journal of Common Market Studies, Vol. 51, No. 1, pp. 105-121. 
Flood, C. (2002) 'The Challenge of Euroscepticism.' In Gower, J. (ed.) The European Union Handbook ( $2^{\text {nd }}$ edition) (London: Fitzroy Dearborn).

Flood, C. (2009) 'Dimensions of Euroscepticism', Journal of Common Market Studies, Vol. 47, No. 4, pp. 911-917.

Forster, Anthony (2002) Euroscepticism in contemporary British politics: opposition to Europe in the British Conservative and Labour parties since 1945 (London: Routledge).

Gaskarth, J. (2013) British Foreign Policy (Cambridge: Polity).

George, S. (1994) An Awkward Partner: Britain in the European Community (2 ${ }^{\text {nd }}$ edition) (New York: Oxford University Press.

Gerring, J. (2001) Social Science Methodology: a Criterial Framework (Cambridge: Cambridge University Press).

Gifford, C. (2008) The Making of Eurosceptic Britain: Identity and Economy in a PostImperial State (Aldershot: Ashgate).

Glynos, J. and Howarth, D. (2008) 'Structure, Agency and Power in Political Analyzis: Beyond Contextualised Self-Interpretations', Political Studies Review, Vol. 6, No. 2, pp. 155169.

Gowland, D., Turner, A. and Wright, A. (2010) Britain and European integration since 1945: on the sidelines (London: Routledge).

Guerra, S. (2013) Central and Eastern European Attitudes in the Face of the Union (Basingstoke: Palgrave Macmillan).

Hay, C. (2011) 'Interpreting Interpretivism Interpreting Interpretations: The New Hermeneutics of Public Administration', Public Administration, Vol. 89, No. 1, pp. 167-182. 
Holden, P. (2011) 'Still 'Leading from the Edge”? New Labour and the European Union.' In Daddow, O. and Gaskarth, J. (eds) British Foreign Policy: The New Labour Years (Basingstoke: Palgrave), pp. 157-169.

Hooghe, L. (2007) 'What Drives Euroskepticism?: Party-Public Cueing, Ideology and Strategic Opportunity', European Union Politics, Vol. 8, No. 1, pp. 5-12.

Jackson, P.T. (2011) The Conduct of Inquiry in International Relations: Philosophy of Science and its Implications for the Study of World Politics (London: Routledge).

Jones, D.M. and Benvenuti, A. (2006) 'Tradition, Myth and the Dilemma of Australian Foreign Policy', Australian Journal of International Affairs, Vol. 60, No. 1, pp. 103-124.

Kabele, J. (2010) 'The Agency/Structure Dilemma: A Coordination Solution', Journal for the Theory of Social Behaviour, Vol. 40, No. 3, pp. 314-338.

Kennedy, P. (1985) The Realities Behind Diplomacy: Background Influences on British External Policy 1865-1980 (London: Fontana Press).

Koene, B.A.S. (2006) 'Situated Human Agency, Institutional Entrepeneurship and Institutional Change', Journal of Organizational Change, Vol. 19, No. 3, pp. 365-382.

Kopecký, P. and Mudde, C. (2002) 'The Two Sides of Euroscepticism: Party Positions on European Integration in East Central Europe', European Union Politics, Vol. 3, No. 3, pp. 297-326.

Leconte, C. (2010) Understanding Euroscepticism (Basingstoke: Palgrave Macmillan, 2010).

Liddle, R. (2014) Britain's European Dilemma: Britain and the Drama of EU Integration (London: I.B. Tauris). 
Ludlow, N.P. (1997) Dealing with Britain: The Six and the First UK Application to the EEC (Cambridge: Cambridge University Press).

Lynch, P. (2011) 'The Con-Lib Agenda for Europe.' In Lee, S. and Beech, M. (eds) The Cameron-Clegg Government: British Politics in an Age of Austerity (Basingstoke: Palgrave Macmillan), pp. 218-233.

Marcussen, M. et al. (1999), "Constructing Europe ? The evolution of French, British and German nation state identities", Journal of European Public Policy, Vol. 6, No. 4, pp. 614633.

Marcussen, M., et al. (2001) 'Constructing Europe? The Evolution of Nation-State Identities.' In Christiansen, T., Jørgensen, K.E. and Wiener, A. (eds) The Social Construction of Europe (London: SAGE), pp. 101-120.

McGowan, F. (2008) 'The Contrasting Fortunes of European Studies and EU Studies: Grounds for Reconciliation?’. SEI Working Paper, No. 99.

Mudde, C. (2011) 'Sussex v. North Carolina: The Comparative Study of Party Based Euroscepticism', EPERN Working Paper, No. 23 (August).

Oppermann, K. (2012) British Foreign and Security Policy: Historical Legacies and Current Challenges (Augsburg: Wissner-Verlag).

Pagden, A. (2002) 'Introduction.' In Pagden, A. (ed.) The Idea of Europe: From Antiquity to the European Union (Cambridge: Cambridge University Press), pp. 1-32.

Parr, H. (2005) Britain's Policy Towards the European Community: Harold Wilson and Britain's World Role, 1964-1967 (London: Routledge).

Paxman, J. (1999) The English: A Portrait of a People (London: Penguin). 
Pine, M. (2012) Harold Wilson and Europe: Pursuing British Membership of the European Community (London: I.B. Tauris).

Poulsen, B. (2009) 'Competing Traditions of Governance and Dilemmas of Administrative Accountability: The Case of Denmark', Public Administration, Vol. 87, No. 1, pp.117-31.

Ray, L. (1999) 'Measuring Party Orientation Towards European Integration: Results from an Expert Study', European Journal of Political Research, Vol. 36, No. 2, pp. 283-306.

Redwood, J. (2001) Stars and Strife: The Coming Conflicts Between the USA and the European Union (Basingstoke: Palgrave).

Rhodes, R.A.W. (2007) 'Understanding Governance: Ten Years On’, Organization Studies, Vol. 28, No. 8, pp. 1243-1264

Rosamond, B. (2007) 'European Integration and the Social Science of EU Studies: The Disciplinary Politics of a Subfield', International Affairs, Vol. 83, No. 2, pp. 231-252.

Ruttley, P. (2002) 'The Long Road to Unity: The Contribution of Law to the Process of European Integration since 1945.' In Pagden, A. (ed.) The Idea of Europe: From Antiquity to the European Union (Cambridge: Cambridge University Press), pp. 228-259.

Schmidt, V. (2001), “The Politics of Economic Adjustment in France and Britain: when does discourse matter ?", Journal of European Public Policy, Vol. 8, No. 2, pp. 247-264.

Schmidt, V. (2008), "Délibération publique et discours de légitimation en France et en Grande-Bretagne face à l'intégration européenne", Revue Internationale de Politique Comparée, Vol. 15, No. 4, pp. 555-571.

Schnapper, P. (2011) British Political Parties and National Identity: A Changing Discourse 1997-2010 (Cambridge: Cambridge Scholars Publishing). 
Schwartz-Shea, P. and Yanow, D. (2012) Interpretive Research Design: Concepts and Processes (London: Routledge).

Smith, M.J. (2008) 'Re-Centring British Government: Beliefs, Traditions and Dilemmas in Political Science', Political Studies Review, Vol. 6, No. 2, pp. 143-154.

Spiering, M. (2004) 'British Eurosceptcism.' In Harmsen, R. and Spiering, M. (eds) Euroscepticism: Party Politics, National Identity and European Integration (Amsterdam: Rodopi), pp. 127-149.

Taggart, P. (1998) 'A Touchstone of Dissent: Euroscepticism in Contemporary West European Party Systems', European Journal of Political Research, Vol. 33, No. 3, pp. 363388.

Taggart, P. and Szczerbiak, A. (2001) 'Parties, Positions and Europe: Euroscepticism in the EU Candidate States of Central and Eastern Europe', OERN Working Paper, No. 2.

Taggart, P. and Szczerbiak, A. (2013) 'Coming in from the Cold? Euroscepticism, Government Participation and Party Positions on Europe', Journal of Common Market Studies, Vol. 51, No. 1, pp. 17-37.

Taylor, P. (2008) The End of European Integration? Anti-Europeanism Examined (Abingdon: Routledge).

Turner, J. (2000) The Tories and Europe (Manchester: Manchester University Press).

Turner, M.J. (2010) Britain and the world in the twentieth century: ever decreasing circles (London: Continuum UK).

Usherwood, S. (2002) 'Opposition to the European Union in the UK: The Dilemma of Public Opinion and Party Management', Government and Opposition, Vol. 37, No. 2, pp. 211-230. 
Usherwood, S. (2007) 'Proximate Factors in the Mobilization of Anti-EU Groups in France and the UK: The European Union as First Order Politics', Journal of European Integration, Vol. 29, No. 1, pp. 3-21.

Usherwood, S. and Startin, N. (2013) 'Euroscepticism as a Persistent Phenomenon', Journal of Common Market Studies, Vol. 51, No. 1, pp. 1-16.

Vasilopoulou, S. (2013) 'Continuity and Change in the Study of Euroscepticism: Plus ça Change?', Journal of Common Market Studies, Vol. 51, No. 1, pp. 153-168.

Verdun, A. (2012) 'Experimentalist Governance in the European Union: A Commentary', Regulation and Governance, Vol. 6, No. 3, pp. 385-393.

Wall, S. (2012) The Official History of Britain and the European Community, Vol.II: From Rejection to Referendum, 1963-1975 (London: Routledge).

Wallace, H. (2013) 'The UK: 40 Years of EU Membership', Journal of Contemporary European Research, Vol. 8, No. 4, pp. 531-546.

Warleigh-Lack, A. (2009) 'Interdisciplinarity in Research on the EU: Politics, History and Prospects for Collaboration.' In Kaiser, W., Leucht, B., and Rasmussen, M. (eds) The History of the European Union; Origins of a Trans- and Supranational Policy 1950-72 (London: Routledge), pp. 206-220.

Wilkes, G. (1997) Britain's Failure to Enter the European Community 1961-63: The Enlargement Negotiations and Crises in European, Atlantic and Commonwealth Relations (London: Frank Cass).

Wilkinson, K. (2011) 'Organised Chaos: An Interpretive Approach to Evidence-based Policy Making in Defra', Political Studies, Vol. 59, No. 4, pp.959-977 
Williams, P.D. (2005) British Foreign Policy Under New Labour, 1997-2005 (Basingstoke: Palgrave Macmillan).

Wintour, P., Watt, N. and Clark, T. (2012) 'Nick Clegg's warning to David Cameron: Britain must stay in Europe', Guardian, 26 December. Available at $<<$ http://www.theguardian.com/politics/2012/dec/26/clegg-warning-cameron-britaineurope $>$.

Young, H. (1998) This Blessed Plot: Britain and Europe from Churchill to Blair (London: Macmillan).

Young, J.W. (2000) Britain and European Unity 1945-1999, (2 ${ }^{\text {nd }}$ edition) (Basingstoke: Macmillan). 